\title{
Niall O'Loughlin
}

Univerza v Loughboroughu

Loughborough University

\section{Ivo Petrić's Orchestral Indian Summer In memoriam Ivo Petrić Indijansko poletje za orkester Iva Petrića In memoriam Ivo Petrić}

Prejeto: 18. december 2018

Sprejeto: 1. marec 2019

Ključne besede: Ivo Petrić, Slovenija, Gallus, Ivan Grohar, Oscar Wilde, Srečko Kosovel, koncert

\section{IZVLEČEK}

Veliko del Iva Petrića je za orkester. Nekatera so povezana z rodno Slovenijo, ostala so koncertantna dela za različne solistične inštrumente. Običajno so komponirana v enem stavku, ki bodisi kažejo povezave $s$ tradicionalnimi ločenimi stavki bodisi gre za dela v več tempih s številnimi medsebojnimi motivnimi povezavami.
Received: $18^{\text {th }}$ December 2018

Accepted: $1^{\text {st }}$ March 2019

Keywords: Ivo Petrić, Slovenia, Gallus, Ivan Grohar, Oscar Wilde, Srečko Kosovel, Concerto

\section{ABSTRACT}

Many of Ivo Petrićs last works are orchestral. Some are related to his native Slovenia, while others are concertos for various solo instruments. They are normally in one movement, either showing some connection with traditional separate movements or multi-tempo works with numerous motivic interconnections.

Throughout his long composing career, the Slovene composer Ivo Petrić (1931-2018) concentrated on instrumental music, partly because of his own early experience as an orchestral oboist and later orchestral manager and artistic director of the Slovenian Philharmonic, and partly from his long and fruitful time as the conductor and leader of the Slavko Osterc Ensemble. ${ }^{1}$ In his early years he composed three symphonies ${ }^{2}$ and a

1 For details of the group's activities see Ivo Petrić, "Jubilej ansambla Slavko Osterc," Zvuki (1973): 39-42 and Andrej Rijavec, "Skladateljska skupina okrog ansambla "Slavko Osterc - Die Komponistengruppe um das Ensemble »Slavko Osterc«," Primož Kuret, ed., Slovenska glasba v preteklosti in sedanjosti - Slowenische Musik in Vergangenheit und Gegenwart (Ljubljana: Kres, 1992), 260-269.

2 The symphonies are Simfonija Goga (3 versions: 1954, 1956 and 1960), Symphony No.2 (1957) and Symphony No.3 (1959-60). 
number of concertos, ${ }^{3}$ mostly for wind instruments, as well as other orchestral works. Petrić's compositions written for the Slavko Osterc Ensemble are also relevant to his development as they gave him invaluable experience in putting into practical terms the vivid instrumental imagination and instrumental combinations that form such an important part of his style. There are a very small number of vocal pieces but, with one exception discussed later, they were not especially important for him.

From around the years 1962 and 1963, he became closely associated with the avantgarde movement in Slovenia, and was a leading member of the composers' group called Pro musica viva which included almost all of the most significant advanced composers of the day. ${ }^{4}$ As the director of the Slavko Osterc ensemble he was able to ensure that all the composers in the group were generously represented on the concert platform and in the recordings that were being made in those years. His style embraced the latest developments, notably aleatory notation. ${ }^{5}$ For this to be effective it was important for the players to be skilfully directed and for a fully working cueing system to be in operation. That this was in fact the case can be deduced from the appearance of a large number of scores published by Edicije Društvo slovenskih skladateljev (The Slovenian Composers Association) which for many years was led by Petrić himself, and numerous successful performances and recordings from this period.

By the mid-1980s Petrić again began to use traditional bar-lines and metrical barring in his compositions. Sometimes this was only a convenience for the performers even if the notation did not indicate a rhythmic dimension, but gradually the significance of the bar-lines became more important as metrical regularity achieved a higher priority. For Petrić a number of his later aleatory scores proved to be less than satisfactory, leading him to rework some of the orchestral scores using the traditional barred notation. Not only were passages rewritten in as straightforward and literal a manner as possible, but also a great deal of other revision took place at the same time, with both expansion and contraction becoming part of the process of transformation. It is not the purpose of the present study to investigate the details of this recasting of earlier works, but rather to focus on the nature of the compositions using the traditional notation which date from the 1980s onwards or those pieces which the composer chose to rewrite using the traditional metrical format.

It is no exaggeration to say that Petrić was busy composing music at a furious rate from then virtually to the time of his death. His music consisted largely of orchestral music, including concertos, ${ }^{6}$ as well as chamber music for one or more performers whose musical characters and technical abilities were well known to him. Inevitably, however, his orchestral works stand high in this period, with some showing an inclination

3 The concertos are for violin (1953), flute (1954-57), clarinet (1958), harp (1959), Koncertantna glasba for bassoon (1959) and Tri skladbe for horn (1961).

4 This is very well covered by Matjaž Barbo in Pro musica viva - Prispevek k slovenski moderni po II. svetovni vojni (Ljubljana: Znanstveni inštitut Filozofske fakultete, 2001). The eight composers he discussed are Jakob Jež (1928), Milan Stibilj (1929-2014), Kruno Cipci (1930-2002), Ivo Petrić (1931-2018), Alojz Srebotnjak (1931-2010), Darijan Božič (1933-2018), Igor Štuhec (1934) and Lojze Lebič (1934). Stibilj stood somewhat apart from the group and Cipci did not feature very strongly. The music of another composer, Primož Ramovš (1922-1999), was frequently performed by the Slavko Osterc Ensemble. A detailed study of Petrić's earlier music (1959-1970) is given by Barbo in Pro musica viva, especially 140-148.

5 Niall O'Loughlin, "Melodic workings in the Music of Ivo Petrić," Muzikološki zbornik 29 (1993), 107-119.

6 See Niall O'Loughlin, "A Return to Old Techniques in Recent Concertos by Ivo Petrić," Muzikološki zbornik 47/1 (2011): 167-176. 
towards programme music and others staying firmly within the area of "absolute music". The total number included in these categories and composed since 1983 consists of at least twenty-seven, ${ }^{7}$ a selection of which form the basis of the present study. The first part of this examination looks at Slovene connections (and one Irish one), while the second part looks closely at Petrić's favourite orchestral form, the concerto.

Petrić always aimed to give an international element to his music, having studied as many contemporary music scores as he could obtain, and having written four impressive articles on contemporary music. ${ }^{8}$ However, he has always treasured his Slovene heritage, taking the opportunity in the 1990s to celebrate that legacy in works that are connected with three different art forms: music, words and painting. The composer's interpretations, it must be emphasised, are subtle in nature and not in any obvious sense programmatically derived.

Because the composer Jacobus Gallus (1550-1591) stands as the Renaissance master who put Slovenia on the musical map, it was only natural that Petrić chose to celebrate his achievement and importance with his own music. His orchestral work called Gallus Metamorphoses of 1992 is in effect a three-movement symphony using motives derived from three of the older composer's motets. One must emphasise, however, that the borrowings are often buried in the musical textures in a way that often makes them difficult to recognise as such. In the first movement, based on the eight-voice motet Quam pulchra est, amica mea, ${ }^{9}$ Petrić very skilfully underpins high woodwind melodic shapes with accompaniments derived from the cantus and altus lines of the first phrase of the motet, in the form of stepwise descending parallel thirds. Rather than using the metre of the original, Petrić maintains a steady crotchet Allegretto grazioso in 3/4 time with percussion (tambourine, timpani, bells, triangle, claves, bongos and wood block) emphasising the modern pulse. The second movement is slow, ${ }^{10}$ in $4 / 4$ time throughout, deriving its borrowed material from the motet Ecce quomodo moritur iustus. ${ }^{11}$ The opening bass clarinet solo follows the beginning of the cantus line, but soon diverges from it chromatically, with other motives being introduced as the movement progresses. As in the first movement they are incorporated into the texture with delicate faster moving string counterpoints playing against the chorale-like quotations from the wind instruments. The haunting coda has chamber-music like textures with the clarinets playing a chorale, reminiscent in some ways of the original motet, and a solo violin and cello decorating this with florid lines. The finale, Vivo giocoso, based on the six-voice Musica noster amor, ${ }^{12}$ returns to the strong rhythmic patterns of the first movement, mostly in 2/4 time with short sections in 3/4. Three elements appear successively: the regular march-like partly dactylic figures from the percussion; wide-spanning melodic phrases from woodwind and strings; and slow moving melodic shapes moving up and down by

7 See Appendix for a list of these works.

8 Ivo Petrić, "Razvoj glasbene misli 20. Stoletja" [Review of 20th-Century Thinking on Music], Sodobnost 10 (1962): 385-96; 509-17; 612-21; 767-80.

9 Jacobus Gallus, Opus musicum, iv/1, no.iv.

10 The opening tempo is not specified in the score, but the recording (Slovenska filharmonija, SF 900045, Ljubljana, 2004), approved by the composer, moves at approximately crotchet $=60$.

11 Jacobus Gallus, Opus musicum, ii/1, no.xiii.

12 Jacobus Gallus, Moralia, xxviii. 
step derived from the Gallus motet. The last develop into chorales quoting Gallus's music even more openly. The movement consists of an interaction of these elements until there is a final synthesis of their different characteristics.

For the second of his orchestral tributes to his native land Petrić turned to poetry in a vocal setting for mezzo-soprano and orchestra. Slovenia has a long and distinguished poetic tradition that extends very much to the present day, from France Prešeren (1800-1849) to Tomaž Šalamun (1941-2014) and Tone Pavček (1928-2011). From the early 20th century one of the most revered poets is Srečko Kosovel (1904-1926). During his tragically short life he witnessed some of the horrors of World War One at first hand and the loss of his Slovene homeland to Italy, both of which fundamentally affected the nature and content of his poetry. It was natural then that Petrić selected some of his poetry for one of his rare vocal settings, the cantata Pesem življenja ('The Song of Life'), originally written in 1981, with a second version in 1984, but whose third and final version was completed only in 1995. This final 26-minute version, first performed in 2001, is methodically planned in an arch form, with poems from Kosovel's Integrali ('Integrals') framing the work and his Rodounik ('The Family Tree') at the centre, which itself is flanked by poetic prose from Ivan Cankar's Kurent and France Forstnerič's poem Pred nemim morjem ('Before the Dumb Sea'). The words, sung by a mezzosoprano, project a powerful and consistent message.

The strong dramatic poetic sequence of the words is clear in performance, which the music reinforces very strongly. The short orchestral prelude opens with a slowmoving and meandering horn solo full of foreboding that has uneasy cello and woodwind counterpoints, building to a climax that sets the tone for the setting of four of Kosovel's Integrali, presenting a world of different evocative colours (blue, green, silver) ending with the climax of "Živeti, živeti je smisel človeka!" ('To live, to live is the purpose of man!'). Petrić always presents the words clearly and scores them modestly, often using sustained sounds to underpin vocal phrases and reintroducing moving orchestral parts during the silences in the vocal part. This triggers a dramatic interlude before the calm passage from Cankar's Kurent. Again the composer builds the music to a climax at the words: "Šaj je le suknja, jaz pa sem mislil, da je človek v nji!" ('It is only the coat, and I thought that the man is inside!'). Kosovel's Rodovnik ('The Family Tree') is even more concise and almost pointillist in character with the repetitive word "suženj" ('slave') beginning each of the first six lines. The quiet and thoughtful interlude and gentle setting of France Forstnerič's Pred nemim morjem ('Before the Dumb Sea') ends with the inscrutable words: "Pred rojstvom je velik prostor. Za smrtjo še večji." ('Before birth there is a great void. After death it is much greater.'). These words and two lines from the earlier Integrali ('Ziveti ...') are repeated as a benediction on the work in the coda to the finale that sets two more of Kosovel's poems.

For the third category of works inspired by Slovenia, Petrić moved from poetry to painting, the works of Ivan Grohar (1867-1911). In 2004 he wrote; "Ivan Grohar is my favourite Slovene painter, and I have a deep attachment to the region from which his family came; the world under Ratitovec is also that of my ancestors." 13 He said that he

13 In the booklet notes for the recording on CD, SF 900045 (Ljubljana: Slovenska filharmonija, 2004). 
constantly returned to the National Gallery in Ljubljana to experience the qualities of Grohar's paintings, something which indicates the deep fascination that these pictures held for him. ${ }^{14}$ The translation of visual art to music is, of course, a controversial subject, something which can vary from crude representation to remote reflections of an abstract nature. In his music Petrić was much closer to the latter, concentrating his tribute in the workings of the music, its melodies and its form. His works that derive their inspiration from Grohar are: Groharjeve impresije ('Grohar's Impressions') of 1980, its newly reworked version Groharjeve impresije II ('Grohar's Impressions II') of 1998, revised in 2003, and Štirje letni časi ('Four Seasons') of 1995-96, revised in 2002. These pieces are all through composed and performed without a break.

Groharjeve impresije II is a 14-minute work with a crotchet beat throughout, but a flexible variety of tempos with the crotchet ranging from 68 to 102, and thus creating an impressive unity (see Table 1 ). The tempo changes always move by step (faster or slower) on a graduated scale from one section to the next. The speed increase or decrease between sections, whenever it has not already been achieved by other means, is normally indicated in the one or two bars before the end of the previous section by poco accel., rit., rallentando, allargando or similar. Each tempo remains steady for a range of between five and 33 bars, presumably an indication of the time the viewer stops to look at each painting. Following the changes in tempo marked by double bars in the score, one can identify 18 sections. It is possible that some of the short sections are simply an indication that the viewer had moved from one painting to another in the same way that Mussorgsky represented with his "promenade" in his Pictures at an Exhibition. The composer gives an indication that a wide range of Grohar's paintings is included in his impressions, although we are not told which section is inspired by which painting. In his note to the recording the composer refers to "a whole gallery of his paintings, ranging from his Spring down to A Larch, Škofija Loka in the Snow, The Sower, A Man with a Cart, The Herdsman, and the rest of the works which have always given me the feeling of national identity and pride." 15 The opening cor anglais solo presents a number of motives that Petrić develops over the course of the work, a feature that gives a clue to its taut unity. Its various chromatic twists and turns are accompanied by contrapuntal motives, while some of the sections are fiercely dramatic in tone. In the fourth section (Passionato agitato), for example, the four horns wind around each other in a counterpoint to threatening rising phrases from the trumpets and trombones.

\begin{tabular}{|c|l|c|c|c|}
\hline Section & Tempo & Metronome & Bars & Pages \\
\hline 1 & Sostenuto meditando & 76 & 16 & $1-3$ \\
\hline 2 & Andantino grazioso & 82 & 9 & $3-4$ \\
\hline 3 & Poco animato & 92 & 16 & $4-6$ \\
\hline 4 & Passionato agitato & 96 & 29 & $7-10$ \\
\hline 5 & Moderato quieto & 76 & 30 & $10-13$ \\
\hline
\end{tabular}

14 Personal recollections to the present writer.

15 In booklet notes for the recording on CD, SF 900045 (Ljubljana: Slovenska filharmonija, 2004). 


\begin{tabular}{|c|l|c|c|c|}
\hline Section & Tempo & Metronome & Bars & Pages \\
\hline 6 & Poco animato & 82 & 15 & $14-16$ \\
\hline 7 & Estatico animato & 102 & 23 & $16-19$ \\
\hline 8 & Moderato quieto & 86 & 20 & $19-21$ \\
\hline 9 & Poco animato & 96 & 33 & $22-26$ \\
\hline 10 & Moderato maestoso & 82 & 11 & $26-27$ \\
\hline 11 & Quasi allegretto & 92 & 16 & $28-30$ \\
\hline 12 & Largo espressivo & 76 & 16 & $30-32$ \\
\hline 13 & Agitato e marcato & 96 & 15 & $32-34$ \\
\hline 14 & Moderato tranquillo & 72 & 15 & $34-36$ \\
\hline 15 & Poco animato & 82 & 5 & 37 \\
\hline 16 & Animato & 96 & 9 & $37-39$ \\
\hline 17 & Moderato quieto & 76 & 19 & $39-42$ \\
\hline 18 & Largo solenne & 68 & 15 & $42-44$ \\
\hline
\end{tabular}

Table 1: Sections of Grohar's Impressions II.

The composer in many of his compositions has given to his music titles which reflect the seasons directly or indirectly. ${ }^{16}$ The second of his orchestral works to trace its inspiration to the paintings of Ivan Grohar, Štirje letni časi ('Four Seasons') limits the number to only four. Thus in this work he focuses on four of the paintings that were briefly referred to in Groharjeve impresije II that can be directly or loosely related to the four seasons: Pomladi ('Spring'), Macesna ('A Larch'), Črednika ('The Herdsman'), and Škofija Loka v snegu ('Škofija Loka in Snow'), spring, summer, autumn, winter, respectively. Again we must not look too closely at the details of the music to reflect literal aspects of the painting, as Petrić was trying more to mirror the mood rather than "painting" a musical picture. The work is structured completely differently from Groharjeve impresije II, although it is similar in length. Petrić takes each of the four pictures in turn, interpolating between each one what he called a "ritornello" which is considerably varied at each appearance, thus creating a work in four sections which are distinguished by metre rather more than tempo. The first section, entitled "Pomlad/ Spring" in the score, in a firmly articulated Allegretto 6/8 time, is built up from an ascending phrase from the clarinets and in imitative entries on the strings. This is one of the composer's favourite methods of building up his textures. The listener can follow the composer's thinking without too much difficulty, but in Petrić's music it is always

16 As well as Štirje letni časi these are Vem za pomlad - cantata (1961), Summer Music for flute and piano (1973), Autumn Music for violin and piano (1974), Winter Music for clarinet and piano (1976), Winter Elegy for oboe and piano (1984), Portrait d'automne for string quartet (1992), Zimska pesem - Winter Song for clarinet and piano (1992), Pomladni concertino (1993), Summer Games for clarinet, cello and piano (1995), Pomladna simfonija - Spring Symphony and Jesenska simfonija - Autumn Symphony (both of 1996), Jesenska srečanja - Autumnal Encounters for clarinet and piano (1998), Winter Games for flute and piano (2002), Autumn concerto for violin and orchestra (2003) and Quatuor 2004 'Après l'automne...' (2004). 
subtly varied and is never predictable. The second picture, Macesna ('A Larch'), ${ }^{17}$ representing summer, provides the inspiration for the next section, but is prefaced by a beautifully scored yearning melodic section for strings and harp. This establishes a 3/4 metre, while the main section maintains the crotchet beat with variable bar lengths. The third painting Črednika ('The Shepherd') representing autumn, is marked to be played Moderato quieto. It is in effect the slow movement, starting with wisps of melodies from the woodwind combined with rising staccato "droplets". Petrić builds up his various mostly rising motives before a brief return to the opening lazy opening oboe phrase with its staccato counterpoint. This is directly followed by the final section, a lively Vivo giocoso in 2/4 time, drawing its inspiration form the painting Škofija Loka $v$ snegu ('Škofija Loka in Snow'). Many of the composer's finales of this period share this strongly rhythmic character with generous use of percussion, sometimes tuned, and short melodic phrases, often passed from instrument to instrument.

The most intriguing orchestral work by Petrić which has extra-musical influence or inspiration must be The Picture of Dorian Gray II. ${ }^{18}$ It began life in its first form in 1983-84 as the symphonic poem Slika Doriana Graya ('The Picture of Dorian Gray') and won first prize in the 1985 Oscar Espla competition in Alicante in Spain where it was first performed a year later. The composer relates that, although he did not attend the premiere, he received a recording of the work. This so displeased him that he lost interest in the piece, until he re-examined it and completely rewrote it in 2007 as Slika Doriana Graya II ('The Picture of Dorian Gray II').

For his inspiration Petrić turned to the novel called The Picture of Dorian Gray by the Irish writer, Oscar Wilde (1854-1900), ${ }^{19}$ which was published first in 1890 in Lippincott's Monthly Magazine. Wilde revised the text, adding a provocative preface when it was published in book form in 1891, but over the years it appeared in a number of versions. ${ }^{20}$ This fantasy story involves a painter, Basil Hallward, who portrays Dorian Gray in a painting as a beautiful young man, with some obvious erotic undertones. There is also a Faustian connection as Dorian Gray becomes involved in numerous questionable activities, including the murder of the painter, in a downward spiral of misdeeds. However, Gray does not immediately suffer, although the subject on the original painting becomes progressively degraded. Finally Gray desperately attacks the painting but in doing so he kills himself, making him old and disfigured in death, while the painting itself is miraculously restored to its pristine beauty.

The plan that Petrić used for the work is similar to that of Groharjeve impresije II, written with a crotchet beat throughout, varying bar lengths, and a total bar count of 500, clearly marked into seventeen sections. In Slika Doriana Graya II the tempos are on a five- point scale from crotchet $=76$ to $112{ }^{21}$ (see Table 2), with 76 marked Quieto

17 The three sections after the first are not titled as such in the score at www.ivopetric.com, but they are identified in the composer's own catalogue of 2001: Opus musicum (Ljubljana: Edicije DSS, 2001), 111-112.

18 Although this work does not have Slovene connections, it is included because of its relevance to the composer's techniques of formal construction.

19 This of course is not connected with Slovenia, but with the London society in which the novel is set. Wilde was more famous for his plays, perhaps most notably The Importance of Being Earnest. The Picture of Dorian Gray was brilliantly transformed into a stage play by the English dramatist John Osborne.

20 Some versions were banned in England, being considered obscene by the standards of the time, and it was only in 2011 that the full text of the novel was finally published.

21 These are 76, 86, 96, 102, 112. 
and 112 marked Vivo giocoso. The tempos alter mostly by step with few sudden changes, making the transitions virtually seamless. To trace the events in the story of Dorian Gray by relating to Petrić's piece, it is best to think in broad terms that indicate the hero's mental disintegration. The music moves from slow mostly quiet sections to those with faster tempos and richer textures and returns to the slower quieter ones, with the faster sections clearly representing the important actions of Gray himself. Petrić uses the opening trumpet motive almost like a motto theme, as the source of much of the melodic material. The rhythms of the derivations of the motives are constantly changed, phrases inverted, and textures built up from the contrapuntal treatment of these motives. The instrumental groups are mainly kept separate, with the brass, mostly trumpets and horns, projecting broad, swinging melodic phrases, woodwind decorating the motives with florid runs, and the strings often presented imitatively, with the use in some of the slower sections of solo instruments, notably violin, viola and cello, in free improvisatory passages. The percussion are used rhythmically, particularly in the faster sections with a strong regular pulse, emphasised by the bongos, timpani and side drum, and melodically by the xylophone and vibraphone, mostly in short phrases.

\begin{tabular}{|c|l|c|c|c|}
\hline Section & Tempo & Metronome & Bars & $\begin{array}{c}\text { Pages in } \\
\text { score }\end{array}$ \\
\hline 1 & Moderato & 86 & 10 & 1 \\
\hline 2 & Quieto & 76 & 9 & $1-2$ \\
\hline 3 & Moderato & 86 & 12 & $2-3$ \\
\hline 4 & Poco animato & 102 & 46 & $3-8$ \\
\hline 5 & Quasi allegretto & 86 & 15 & $8-10$ \\
\hline 6 & Quieto & 76 & 23 & $10-12$ \\
\hline 7 & Poco animato & 96 & 31 & $12-16$ \\
\hline 8 & Quieto & 76 & 14 & $16-17$ \\
\hline 9 & Vivo giocoso & 112 & 97 & $18-28$ \\
\hline 10 & Quieto & 76 & 12 & 29 \\
\hline 11 & Moderato & 86 & 39 & $30-34$ \\
\hline 12 & Animato & 102 & 10 & $34-35$ \\
\hline 13 & Vivo giocoso & 112 & 97 & $36-46$ \\
\hline 14 & Moderato & 86 & 28 & $46-49$ \\
\hline 15 & Animato & 102 & 17 & $50-52$ \\
\hline 16 & Moderato & 86 & 24 & $52-55$ \\
\hline 17 & Quieto & 76 & 15 & $55-56$ \\
\hline
\end{tabular}

Table 2: Sections of The Picture of Dorian Gray II. 
The second main area of Petrić's later orchestral music to be considered here is the concerto. From his earliest compositions the concerto featured strongly in his output, ${ }^{22}$ and in his last years he produced a number of works which employed a solo instrument or instruments, concertos for trumpet (1985-86), alto saxophone (1997), horn (1997), marimba (2005), and two concertinos, Pomladni concertino ('Spring Concertino') for percussionist in 1993 and the Concertino doppio for flute, horn and strings with piano in 2007. There were two solo string concertos, Autumn Concerto for violin and orchestra (2003) and the Fantasia concertante for viola and orchestra (2011), as well as the Dresdener Konzert for strings of 1987 which relies less on the use of solo instruments, and the Second Concerto for orchestra of $2009 .{ }^{23}$ The focus in this paper is on the first three solo concertos (for trumpet, saxophone and horn), the two concertinos (Pomladni concertino and Concertino doppio) and the Second Concerto for Orchestra.

In these works we can see how Petrić has turned his "reinvented" style to his own advantage, instilling into each work recognisable features that identify the compositions in a unique way. Because the composer has an expert knowledge of instrumental abilities drawn from his long experience with his performing group, it is no surprise then that the character of each concerto is determined to a great extent by the capabilities of the solo instruments used. For each concerto further details of the techniques employed are briefly discussed to give some clues to the nature of the works.

The Trumpet Concerto casts the soloist in a clear melodic role. Although there are occasional suggestions of military style, the trumpet here is primarily a singing instrument with full chromatic abilities across the whole range. Some of the character of the trumpet part can be inferred from Example 1, taken from the second main section, in particular the smooth scalic runs, the chromatic alterations within phrases and the highly imaginative rhythmic variety. One notes in particular the alternation of bars of $3 / 4$ and $4 / 4$, the two three-note motives, the first consisting of two rising or descending whole tones, and the second a falling whole tone followed by a rising semitone (bar 2 and bar 4).

The opening section of the concerto is preparatory in two ways: it introduces the main slow first movement, but it also presents some important music. All the instruments chart an arch-shape with the melodic material, something which features strongly as the work progresses. The trumpet's music is clearly defined but the accompanying music is less easy to hear as the overlapping rising and falling phrases are infiltrated into the contrapuntal texture. This is skilfully combined with a rising and falling semiquaver figure that is frequently taken by the soloist but also forms part of the intricate accompaniment. The main fast section (Allegretto scherzando) uses a brilliant combination of the rising and falling semiquaver figure and thematic material presented by the trumpet in Example 1. The brief slow movement (Largo cantabile) has an elaborate trumpet ornamentation with mostly descending heterophonic phrases from the orchestra. The transition to the fast final section uses the wa-wa mute in a very intense section slightly suggestive of jazz. In the Giocoso vivo the brilliant trumpet part elaborates much of the accompanying material. 


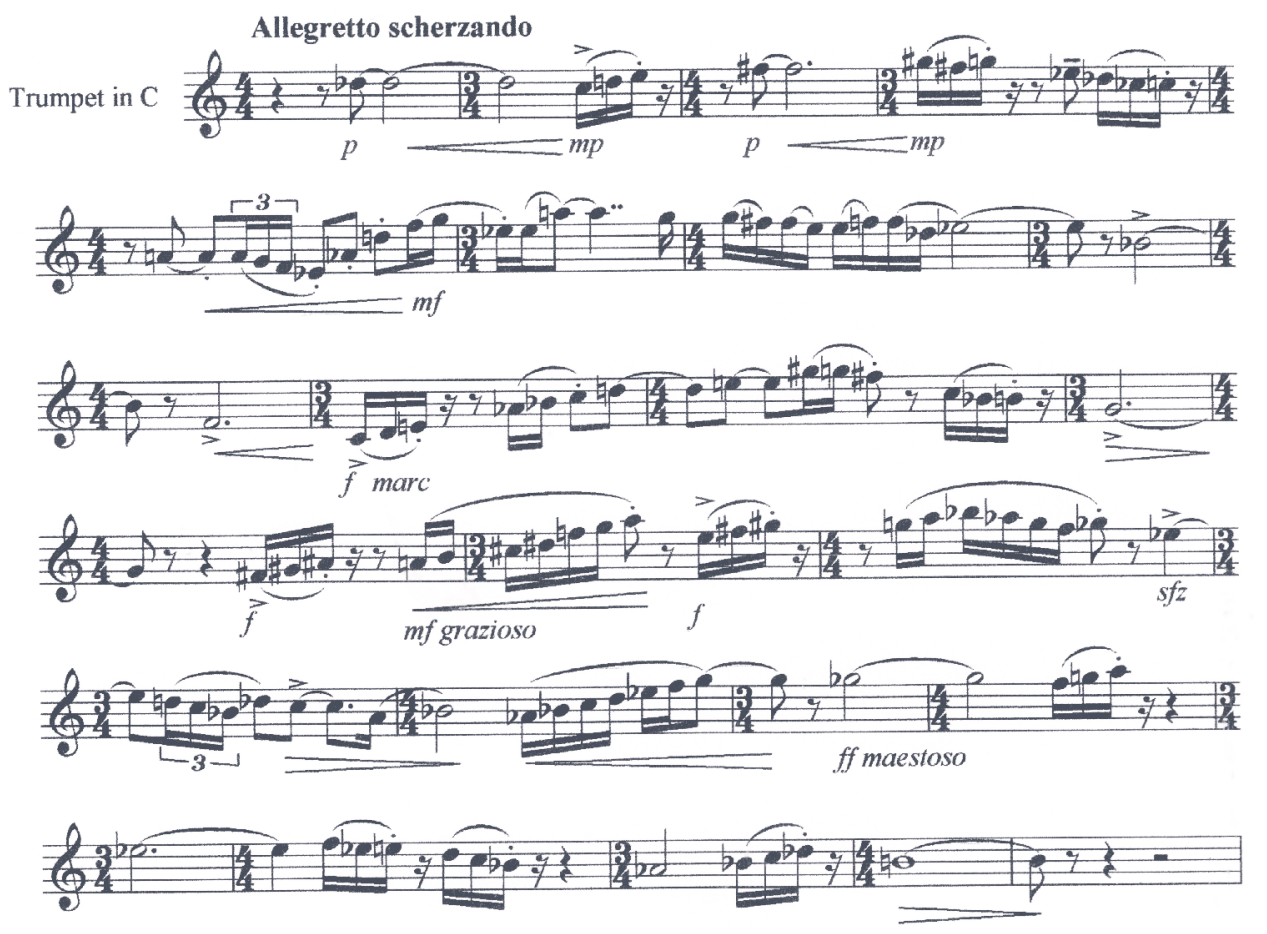

Example 1: Koncert za trobento in orkester (Edicije DSS 1166), pp. 17-21, bars 110-133.

The second concerto, the Pomladni concertino for percussion, has a completely different approach to the melodic material because of the solo instruments used. The predominant instrument is the vibraphone, but the more rhythmic sections employ the xylophone and the slow section the glockenspiel. Example 2 gives some idea of the character of the music for vibraphone with arpeggiated writing which falls naturally under the hands. Note though that while the chordal shapes are laid out in traditional patterns, the notes do not normally mark out diatonic chords or scales thus keeping the tonality in a state of constant flux. Sudden chromatic changes in fast moving scalewise passages that were such a feature of the trumpet concerto and also the saxophone concerto are not so frequent in this concertino. There are infrequent opportunities for chords. The last two lines of Example 2 show a number of two-note chords.

The character of the Pomladni concertino is very vivid with strong instrumental colours. The short introduction is highly atmospheric with no clearly defined tonality, the chords being built up one note at a time. The free tonality is emphasised by the vibraphone's chromatically inflected chords and melodic phrases. The main opening Allegro moderato is interestingly constructed. The vibraphone part (see Example 2) is supported by repeated chords on the horns and violins, but it is also complemented by a subtle contrapuntal network of phrases from most of the orchestra. This section 


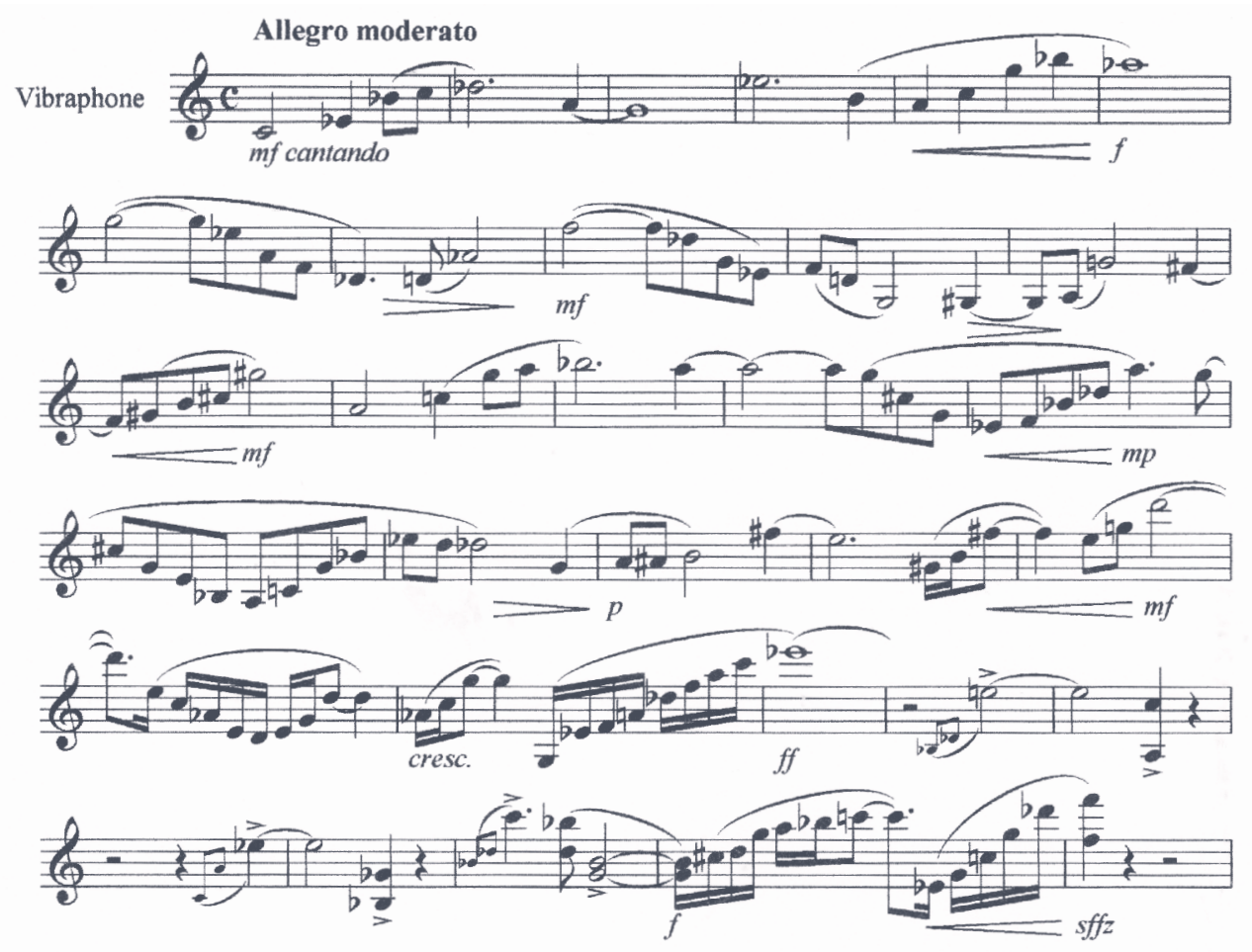

Example 2: Pomladni concertino (Composer's score: www.ivopetric.com), pp. 3-7, bars 9-39.

is divided almost in the middle by a cadenza that develops some of the motives. The return to the Allegro moderato is in effect a "recapitulation", not in the literal sense but a reworking of much of the earlier music. For the Scherzando animato, the xylophone is introduced almost hesitantly, but soon it displays its virtuosic nature. Again Petrić assigns both repeated chords and counterpoints to the orchestra, and also introduces a xylophone cadenza fairly close to the end of the section. Surprisingly the slow "movement" uses the glockenspiel with arpeggiated phrases. It is at the end of this section that the composer changes to the vibraphone in similar style for the accelerating section that leads into the xylophone's Vivo scherzando. In this part Petrić makes the soloist's relationship with the orchestra one of dialogue and imitation. The important final structural feature of the work is the long coda for vibraphone which recalls a number of earlier motives. The formal effect of this section is one of enclosing the potentially disparate elements of the work in a neat and tidy way.

The Concerto for alto-saxophone and orchestra dates from 1997. It treats the instrument in a virtuoso fashion with many florid runs as well as arpeggios as found in the Pomladni concertino. Example 3 shows the particularly extravert nature of the solo part, with non-diatonic arpeggios and scales and sudden shifts of harmonies within 
Allegretto giocoso
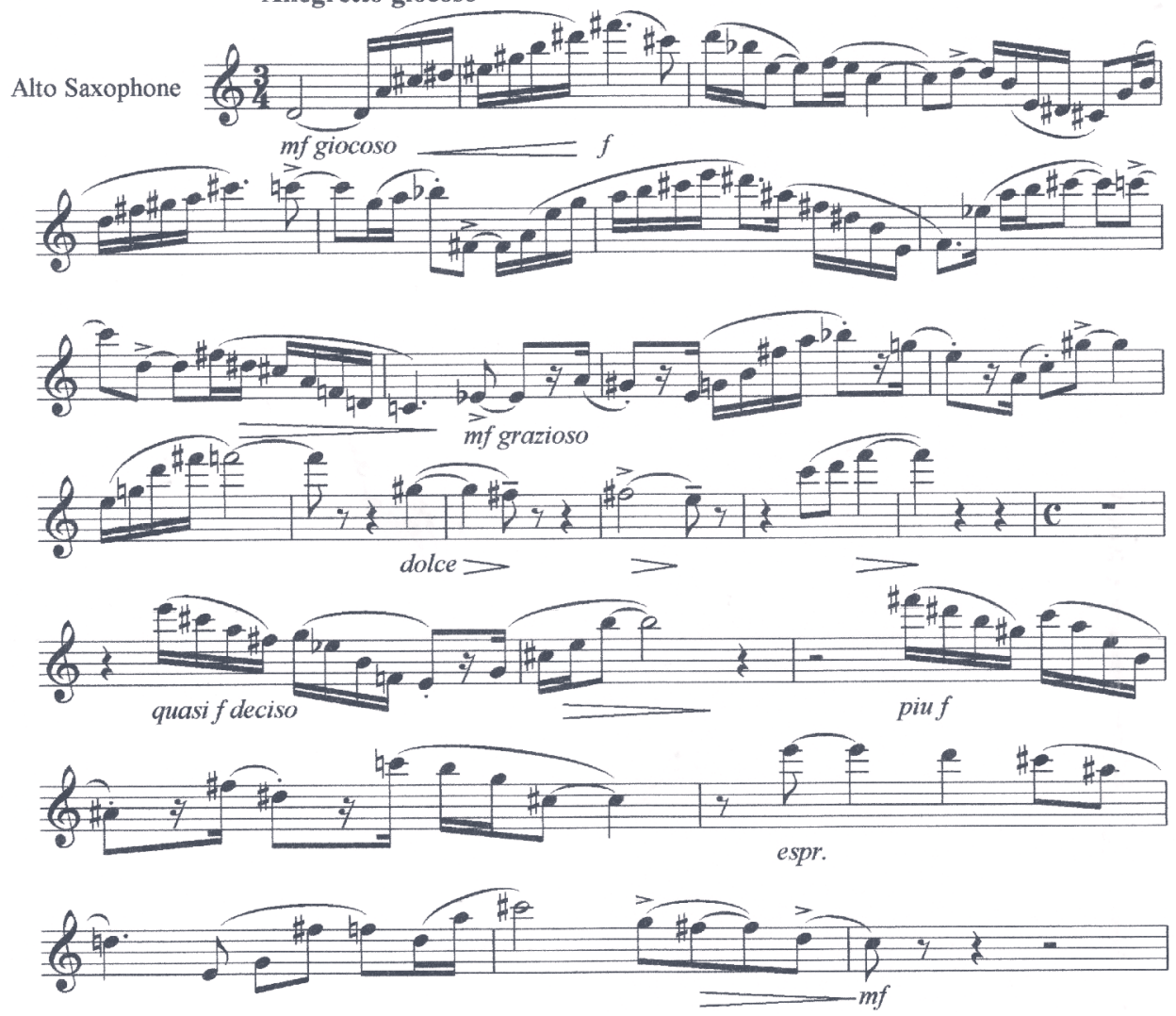

Example 3: Koncert za alt-saxophon in orkester (Composer's Score: www.ivopetric. com), pp. 2-5, bars 13-40.

the same phrase. The full range of the instrument is employed to great effect. Rhythmic phrases are sometimes repeated with different notes, but more often the rhythmic structures are changed at each appearance giving the work unity without any form of predictability. One is reminded from time to time of various aspects of jazz idiom even though the music owes only a very small amount to the style. Rhythmic flexibility is important in defining the character of the solo part, with syncopation frequently used as part of this process (see bars 3-10 of Example 3).

Brief rhythmic ostinatos prepare the listener for the dramatic opening giocoso entry of the saxophone (see Example 3). The passage is accompanied by subtle and intriguing counterpoints, notably from the celesta and vibraphone, in a movement of delicate orchestration. In fact, the light textural weavings of the orchestra prove a perfect foil to the virtuoso solo line. An extended cadenza, sometimes accompanied by percussion, leads into the dreamily chromatic Andante moderato whose contrapuntal 


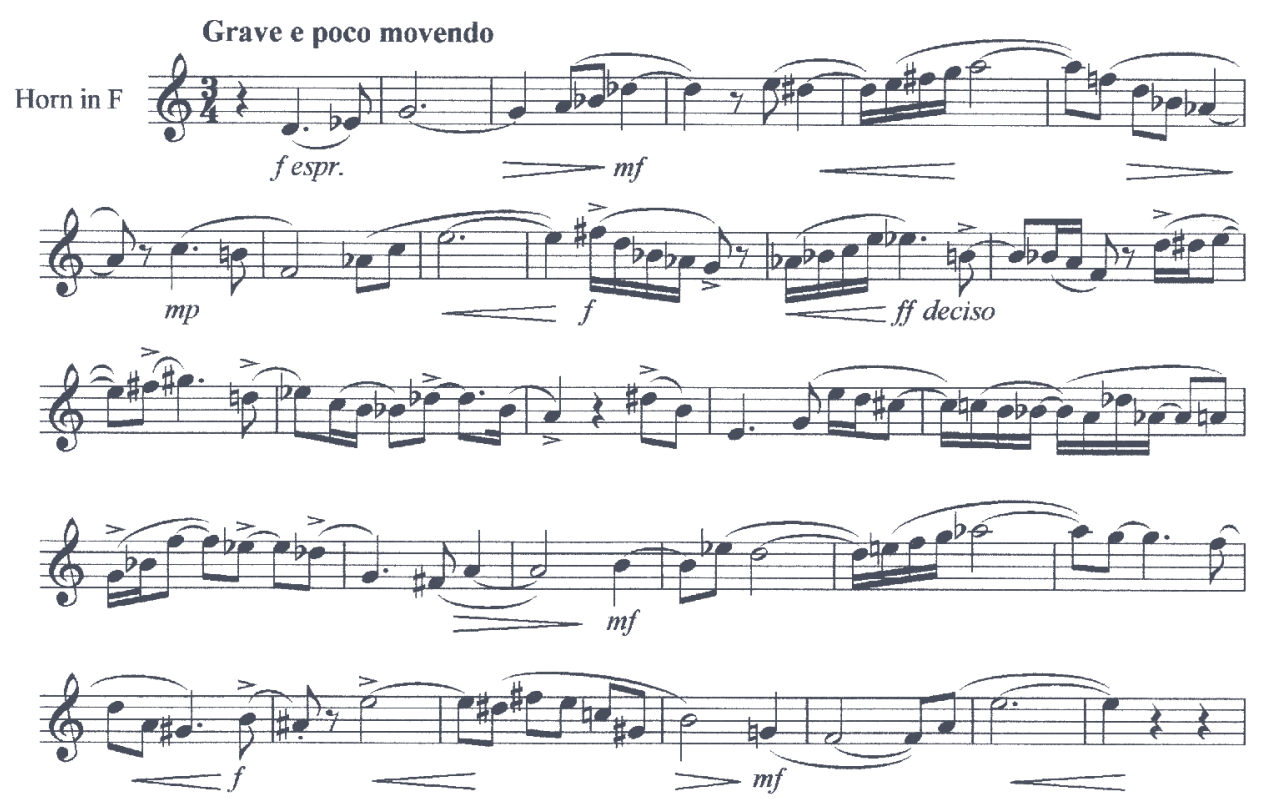

Example 4: Koncert za rog in orkester (Composer's Score: wwwivopetric.com), pp. 39-42, bars 295-324.

string textures allow the solo to stand out. Another cadenza, now brief and again accompanied by percussion, leads to the final Vivo giocoso, rhythmically solid to anchor the saxophone's fluid passage work with its numerous syncopations. The only interruption to the section's momentum is a sixteen-bar Andante which recalls some earlier thematic material, before the final return to the fast tempo launched with stamping four-note chords (B flat, D flat, A flat, C).

The Concerto for horn and orchestra is the most serious of the concertos presented here. It is less concerned with elaborate exuberance than the Saxophone Concerto or the playful rhythmic xylophone sections of the Pomladni concertino. Example 4 presents a passage in the slow third main section that is the emotional heart of the work. In many ways its melodic lines are similar in some ways to those of Gustav Mahler and show the same generally easy movement by step or small leaps. Petrić, of course, does not use Mahler's tonal language so the frequent chromatic inflections are not linked to diatonic harmony as Mahler's are, but they still have the same emotional effect. The arch shape of many of Mahler's melodic lines is also found in Petrićs concerto and in particular the slow section (or movement) shown in Example 4, something also noted in the earlier part of the Trumpet Concerto.

The opening section is an extended movement without obvious changes of tempo (Moderato mosso) and leads into a similarly structured Allegretto scherzando movement. Orchestral textures are exquisitely imagined and carefully gauged with an 


\section{Moderato}

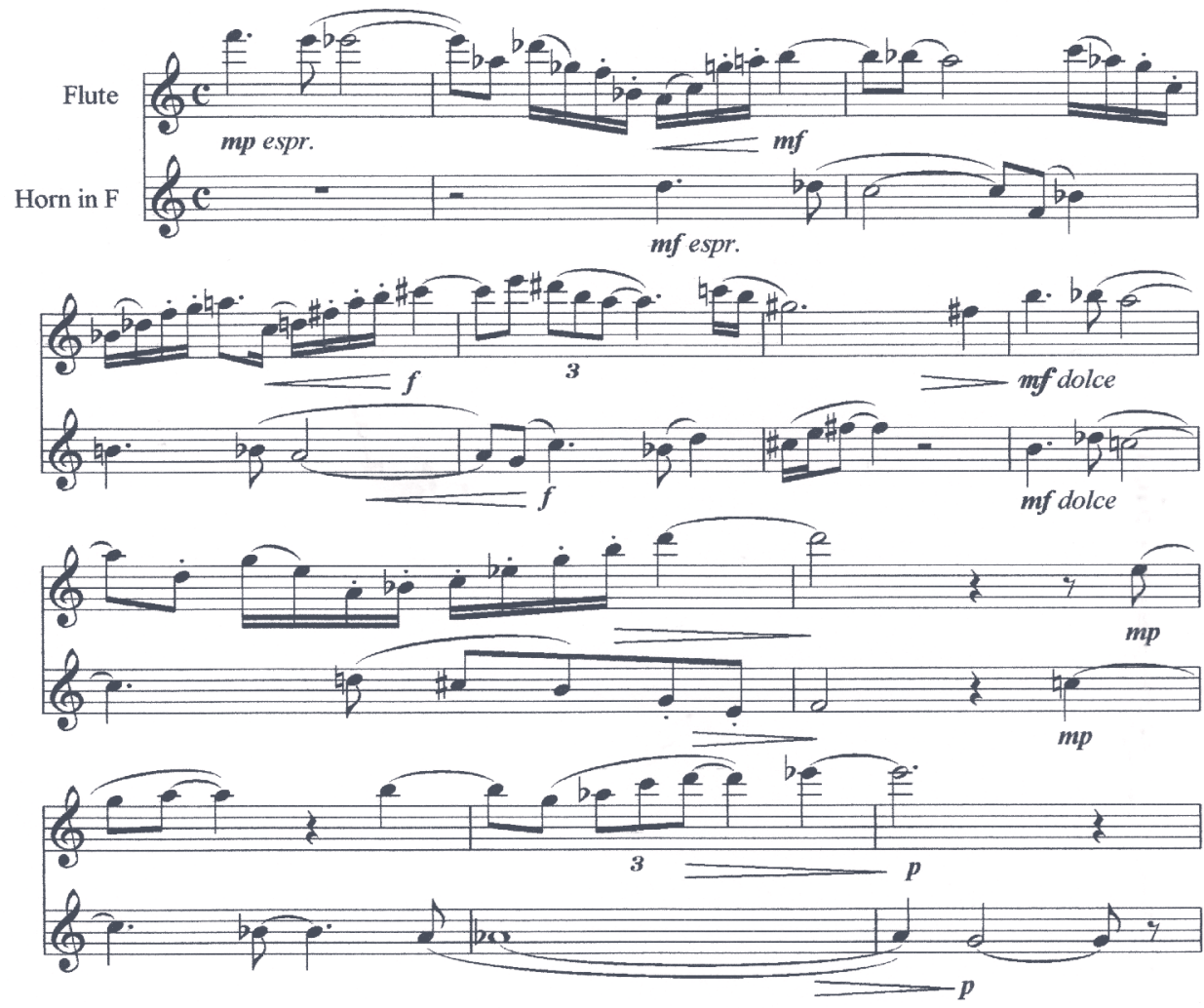

Example 5: Doppio concertino (Composer's Score: www.ivopetric.com), pp. 5-6, bars $68-79$.

emphasis on high and low sounds leaving the middle register clear for the horn to sound effectively. There is an emphasis on motives that are extensively transformed and used for structural definition. The scherzando movement merges into a cadenza-like section accompanied by percussion, piano and harp. This leads directly into the slow movement, richly harmonised, at first by the strings and then by the wind to accompany the horn's expansive melodic line (see Example 4). The finale (Allegro) reintroduces motives from earlier in the work in further development of the musical material. Unlike the florid ending of the Saxophone Concerto but more like the longer slow coda that concludes Pomladni concertino, Petrić broadens the tempo, Poco largamente e maestoso, which allows the soloist to end emphatically with a modern fanfare.

While Petrić has composed a large number of solo concertos, the Concertino doppio of 2006 for flute, horn, strings and piano is a rare example of a double concerto. ${ }^{24}$

24 There were two concertante works from 1975 for two instruments Gemini Concerto for violin, cello and orchestra and Gemini Concertino for violin, horn and six instruments 
It offered a good opportunity to contrast and combine the techniques and individual characters of the different instruments. In it Petrić creates broad, sweeping melodic lines for the horn and more florid scalic runs and arpeggio-type figures for the flute, which are carefully woven together (see Example 5), occasionally assisted by the piano. The main string body varies its contribution from simple chordal accompaniments to imitative, contrapuntal melodic phrases using some of the motives originally played by the two soloists. The composer again casts the work in a single multi-tempo movement (see Table 3), all 292 bars in 4/4 time, except for bar 235 which is in 5/4 time. The main sections are moderately fast (Più mosso), fast (Vivo giocoso) and fairly slow (Moderato). The extended Vivo giocoso returns as the finale, interrupted only by a short but beautiful contrapuntal Largo for the flute and horn with a walking pizzicato double bass part and some interjections from the piano.

\begin{tabular}{|c|l|c|c|c|}
\hline Section & Tempo & Metronome & Bars & Pages \\
\hline 1 & Moderato & 86 & 10 & 1 \\
\hline 2 & Più mosso & 96 & 92 & $1-8$ \\
\hline 3 & Moderato & 86 & 6 & 8 \\
\hline 4 & Vivo giocoso & 112 & 40 & $8-13$ \\
\hline 5 & Moderato & 86 & 19 & $13-15$ \\
\hline 6 & Più largo & 76 & 5 & 15 \\
\hline 7 & Più mosso & 96 & 30 & $16-18$ \\
\hline 8 & Moderato mosso & 96 & 34 & $19-22$ \\
\hline 9 & Vivo giocoso & 112 & 27 & $22-25$ \\
\hline 10 & Largo & 76 & 10 & 25 \\
\hline 11 & Vivo giocoso & 112 & 19 & $26-27$ \\
\hline
\end{tabular}

Table 3: Sections of Concertino doppio.

The "Concerto for Orchestra" as the title for an orchestral work has a long tradition which stretches back to the 1920s. The most famous work with this title, of course, is that by Béla Bartók which dates from 1943, but preceding it were the Concerto for Orchestra by Paul Hindemith (1925) and another by Zoltán Kodály (1939-40), as well as the works entitled Koncert za orkester by Lucijan Marija Škerjanc of 1926 and by Slavko Osterc of 1932. Since Bartók's work the title has been very commonly used by many composers, for example Witold Lutosławski (1954), Michael Tippett (1963), Roberto Gerhard (1965), Elliott Carter (1970) and others. In most cases it was intended to be a showpiece in which all the instruments are to display their capabilities, although some composers hesitated to make the work a virtuoso composition for orchestral instruments. Originally Petrić composed his Concerto for Orchestra in 1982, but was dissatisfied with it. In 2009 he wrote a new work which used some of the music from the original, now in normal barred notation, which he called Second Concerto for Orchestra. 
Like Bartók's, Petrić's Second Concerto for Orchestra is cast in five movements in an arch plan (fast, slow, fast, slow, fast), but unlike its predecessor with the central movement faster than the two flanking movements (see Table 4). Further differences are that it plays without a break and lasts only fourteen minutes.

\begin{tabular}{|c|l|c|c|c|c|}
\hline Section & Tempo & Metre & Metronome* $^{*}$ & Bars & Pages \\
\hline 1 & Vivo ed energico & $2 / 2$ & 96 & 90 & $1-10$ \\
\hline 2 & Andante & $3 / 4$ & 92 & 50 & $11-15$ \\
\hline 3 & Allegretto giocoso & $3 / 4$ & 112 & 94 & $16-27$ \\
\hline 4 & Moderato & $4 / 4$ & 86 & 50 & $28-34$ \\
\hline 5 & Allegretto giocoso & $3 / 4$ & 102 & 126 & $35-50$ \\
\hline
\end{tabular}

*Minim beat for first movement, crotchet beat for movements 2 to 5 .

Table 4: Sections of the Second Concerto for Orchestra.

As in all works such as this it is natural to turn to the use of the orchestra. Petric used a full orchestra with a large percussion section, which is extensively employed in the faster sections. While the first movement makes great play with many repeated quavers, the two movements marked Allegretto giocoso have much more interesting percussive patterns from bongos, woodblocks and various drums. Tuned percussion (xylophone and marimba especially) are liberally used, sometimes in their melodic guises and at others to double the woodwind lines. In the faster sections the woodwind play in both homophonic and imitative textures. A particularly notable two-part passage for clarinet and bass clarinet appears in the third movement. Passages for solo instruments are more common in the slower second and fourth movements. For example the opening of the second fourth movement features a beautiful cor anglais solo that twists and turns unpredictably (Example 6), while similar solos for cello, viola and violin are found in the

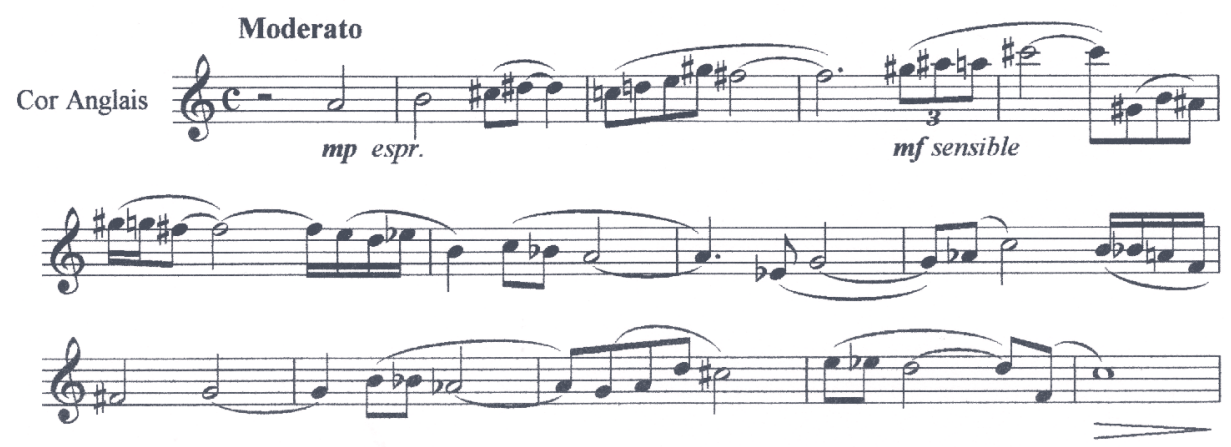

Example 6: Second Concerto for orchestra (Composer's Score: www.ivopetric.com), pp. $28-30$, bars 239-52. 
second movement which begins with an extended bass clarinet solo. The brass section is used in the traditional fashion of strengthening textures, but also with short passages of important melodic writing. Formally the structure does not follow traditional plans, but rather consist of a constant development of motives.

To sum up Petrić's contribution to the orchestral repertory in his last years, two areas should be emphasised. The first is that the composer always valued the nature of the different instruments and the contribution that they make to a total texture. In some ways it is the sound quality or colour in which he was interested, but in other ways it is also the fluid technique of woodwind, the expressive and florid nature of the string instruments, the majesty of the brass and the rhythmic verve of the percussion. This is emphatically the case with the Second Concerto for Orchestra. The second is the grasp of effective musical form. Some works, notably the concertos for trumpet, percussion, saxophone and horn, as well as Štirje letni časi ('Four Seasons') display a subtle but clear acknowledgement of traditional forms, but disguise the process by means of skilful transitions and unorthodox 'insertions'. Other works, for example, Groharjeve impresije II ('Grohar's Impressions II'), The Picture of Dorian Gray II and the Concertino doppio, explore a single-movement flexible approach which knits together the many different tempos in a plan which mostly moves by step from one speed to the next, either faster or slower. In short, it is his delight in the effective use of instruments and his wonderfully refreshing view or review of traditional forms that characterise these impressive works. It is not unreasonable to call this late blossoming of orchestral inspiration by Petrić as his "Orchestral Indian Summer".

\section{Appendix \\ Ivo Petrić's orchestral works composed since 1983}

Leipziger Kammermusik (1983)

Concerto for trumpet and orchestra (1985-86)

Dresdener Konzert (1987)

Moods and Temperaments (1987)

After So Many Years (1988-89)

Gallus Metamorphoses (1991-92)

Pomladni concertino (1993)

Pesem življenja - Song of Life [third version] (1995)

Štirje letni časi - Four Seasons (1995-96, revised 2002)

Pomladna simfonija - Spring Symphony (1996)

From Scottish Diary (1996)

Jesenska simfonija - Autumn Symphony (1996)

Concerto for horn and orchestra (1997)

Concerto for saxophone and orchestra (1997)

Groharjeve impresije II - Grohar's Impressions II (1998, revised 2003)

Three Places in Scotland (2000)

Autumn Concerto for violin and orchestra (2003) 
Scottish Impressions (2003)

Concerto for marimba and orchestra (2005)

Concertino doppio for flute, horn and strings (2007)

Chamber Symphony 9607 (2007)

Toccata giociosa (2008)

The Picture of Dorian Gray II (2008)

Second Concerto for orchestra (2009)

Landscapes of Memories (2010)

Fantasia concertante for viola and orchestra (2011)

Places for My Soul (2015)

\section{POVZETEK}

Skladatelj Ivo Petrić (1931-2018) se je osredinjal na inštrumentalno, v glavnem orkestralno glasbo - še zlasti v poznih letih. Od leta 1983 je uglasbil vsaj 27 del za orkester, ki so vsa napisana v običajnih metričnih oblikah, pri čemer je nekatera predelal iz starejših različic v aleatoričnih notacijah. Med njimi nekatera ustvarjajo zunajglasbene povezave, medtem ko so druga kot taka neprogramska. Študija se posveča tistim delom, povezanim s Slovenijo in tistim s koncertno obliko, ki je bila skladatelju najljubša. Petrićeve Gallusove metamorfoze črpajo nekatere glasbene dele iz Gallusovih motetov, njegova Pesem življenja se naslanja na besede slovenskih pesnikov Srečka Kosovela, Ivana Can- karja in Franceta Forstneriča, slike Ivana Groharja pa so navdahnile Groharjeve impresije II in Štiri letne čase na nekoliko zrahljan programski način. Poleg tega temelji Slika Doriana Grayja II na romanu irskega pisatelja Oscarja Wilda, v skladbi pa skladatelj $\mathrm{v}$ enem stavku $\mathrm{z}$ več tempi upodobi zgodbo v glasbeni preobrazbi. Solistični koncerti za trobento, tolkala, saksofon in rog slikajo celostno zavedanje zmogljivosti vsakega od inštrumentov in to $\mathrm{v}$ delih, ki so modelirana po prefinjenih razširitvah tradicionalnih oblik. Concertino doppio in Drugi Koncert za orkester se poslužujeta fleksibilne oblike z več tempi iz Groharjeve impresije II in Slike Doriana Grayja II in obe kažeta jasno zavedanje sposobnosti sodobnih glasbenikov ter karakterja in tehnik njihovih inštrumentov. 